\title{
Survival analysis of penile cancer patients treated at a tertiary oncology hospital
}

\author{
Análise de sobrevida de pacientes com câncer de pênis \\ tratados em um hospital oncológico terciário
}

\author{
Marco Antônio Comper de Souza ${ }^{1}$ \\ Sérgio Riguete Zacchi ${ }^{1}$ \\ Katia Cirlene Gomes Viana ${ }^{2}$ \\ Camila Brandão de Souza ${ }^{3}$ \\ Eliana Zandonade ${ }^{1}$ \\ Maria Helena Costa Amorim ${ }^{1}$
}

\footnotetext{
${ }^{1}$ Programa de Pós-

Graduação em Saúde Coletiva pela Universidade Federal do Espírito Santo. Av. Fernando Ferrari s/n, Goiabeiras. 29060-900 Vitoria ES Brasil.marcocomper@ yahoo.com.br

${ }^{2}$ Hospital de Câncer do Hospital Santa Rita de Cássia/Afecc.

${ }^{3}$ Programa de PósGraduação de Enfermagem, Universidade Federal de São Paulo. São Paulo SP Brasil.
}

\begin{abstract}
This article aims to estimate the specific survival of patients with penile cancer treated at a state tertiary oncology hospital. The study included 100 cases incidents patients with penile cancer treated at a cancer center, from 2000 to 2011, follow-up to December 31, 2012. The hospital-based cancer registry and medical records were used as data sources. We used the Kaplan-Meier method to estimate survival and the Cox model was used to assess prognostic factors. All had histology for penile cancer as a basis for diagnosis. For location of the 75\% tumor were not specified, followed by $18 \%$ located in the glans, $04 \%$ in the foreskin. The median survival time was 49 months, 89\% presented themselves between stages I and II. Patients with rural occupations had a mean survival time of 75.02 months, patients with non-rural occupations 42.14 months; Patients residing in metropolitan area - Espirito Santo had a mean survival time of 26.03 months, other patients 71.42 months; In patients with compromised lymph nodes, the mean survival time was 30.59 months, and in patients with no compromised lymph nodes, the mean survival time was 75.83 months. This study demonstrates reduced survival in non-rural workers who reside in metropolitan area and who present with compromised lymph nodes and metastasis.
\end{abstract}

Key words Penile neoplasms, Survival analysis, Public health policy
Resumo $O$ objetivo deste artigo é estimar a sobrevida específica dos pacientes com câncer de pênis atendidos em um hospital de referência em oncologia. Analisou-se 100 casos incidentes de pacientes com câncer de pênis que receberam tratamento no hospital, no período de 2000 a 2011, seguimento até 31 de dezembro de 2012. Utilizouse como fonte de informação o banco de dados do Registro Hospitalar de Câncer e o prontuário do paciente. Utilizou-se o método de Kaplan-Meier para estimar a sobrevida e o modelo de Cox para investigar os fatores prognósticos. Todos possuíam histologia para câncer do pênis como base para o diagnóstico da doença. Para localização do tumor $75 \%$ não foram especificados, seguido de 18\% na glande, $04 \%$ no prepúcio. O tempo mediano de sobrevida foi de 49 meses, $89 \%$ apresentavam-se entre os estádios I II. Pacientes com ocupação rural apresentaram sobrevida média de 75,02 meses, ocupação não rural de 42,14 meses. Os procedentes da Grande Vitória - Espírito Santo sobrevida média de 26,03 e demais pacientes de 71,42 meses. Homens com linfonodo positivo possuíram sobrevida média de 30,59 meses e, sem comprometimento, 75,83 meses. A presença de metástase esteve associada a menores taxas de sobrevida. Trabalhadores não rurais, proveniente da Grande Vitória, com presença de linfonodo acometido e metástase apresentaram pior sobrevida.

Palavras-chave Câncer de pênis, Análise de sobrevida, Políticas públicas de saúde 


\section{Introduction}

The incidence of penile cancer varies around the world, and penile cancer is generally considered a rare cancer ${ }^{1}$ with an incidence of 0.6 per $1,000,000 /$ year $^{2}$. However, in developing countries, penile cancer is observed more frequently ${ }^{3}$, particularly in Africa and South America, and the environmental factors, chronic papillomavirus infections and poor hygienic conditions play an important role in occurrence of penile cancer. ${ }^{1}$

Penile cancer has a high mortality rate ${ }^{4}$, ranging from 26.7 to $41 \%{ }^{5}$. The incidence rates vary among different populations, with the highest cumulative rates seen in parts of Uganda and 300 -fold less, found among Israeli Jews ${ }^{1}$. In Brazil represents $2 \%$ of male cancers in 2013 was responsible for the deaths of 396 men $^{6}$.

Disease progression in untreated patients leads to death within 2 years in most cases ${ }^{7}$, and for patients with more advanced cases the first year after diagnosis is the most critical, given the rapid disease progression and treatment ineffective ${ }^{8}$. Complications deriving from tumour growth in areas of lymphatic spread, such as necrosis, sepsis, cachexia, and bleeding resulting from the erosion of the femoral vessels ${ }^{9}$.

Lymphatic spread is the main prognostic factor in penile cancer ${ }^{10}$, although other factors influence survival rates in penile cancer patients, such as locally advanced stage, perineural invasion, location and size of the tumour, growth pattern and high histological grade ${ }^{11}$. Relative survival rates for penile cancer in Europe are high in one and five years, respectively, 85.8 and $68.4 \%$, with conditional survival of approximately $80 \%{ }^{8}$. For patients with compromised inguinal lymph nodes, this rate decreases to 30 to $50 \%$, and when there is invasion of iliac lymph nodes, the survival rate is less than $20 \%{ }^{12}$.

Considering these data, we conduct a study to estimate the survival of patients with penile cancer treated on a universitary, philanthropic and tertiary oncology hospital at a state.

\section{Materials and Methods}

It is a retrospective cohort study. The study population was composed of 108 patients diagnosed with penile cancer treated at Santa Rita de Cássia Hospital (Hospital Santa Rita de Cássia - HSRC)/ Women's Association for the Education and Fight Against Cancer (Associação Feminina de Educação e Combate ao Câncer - Afecc), located in Vitória, Espírito Santo, Brazil, from 1 January 2000 to 31 December 2011. Eight men were excluded from the study because they were followed at HSRC for less than 6 months. The final number of cases analysed was 100 . We did not include cases with recurrent disease.

Data were collected from the Tumour Registry of HSRC/Afecc, a tertiary referral centre for cancer treatment, established as a Centre of High Complexity in Oncology (Centro de Alta Complexidade em Oncologia - CACON) by Brazilian Ministry of Health.

The Tumour Registration Form and the medical records of men diagnosed with penile cancer and treated at HSRC were registered on the hospital's health information system. From these data, we could identify sociodemographic and clinical variables (age range, race/skin colour, educational level, occupation, place of residence, marital status, source of referral, previous diagnosis, staging, presence of lymph node invasion, and metastasis).

Other variables related to risk factors (phimosis, smoking, chronic balanoposthitis, poor hygiene, HPV infection, scleroatrophic lichen, cutaneous horn, keratotic balanitis, balanitis xerotica obliterans, and leucoplakia) ${ }^{3,13}$ were not used in this study due to incomplete data.

Deaths and causes of death were identified via the Mortality Information System (Sistema de Informaçoes sobre Mortalidade - SIM) of Espírito Santo state from 2000 to 2012. Penile cancer was defined as the cause of death for cases registered with diagnostic code ICD C60, according to the 10th edition of the International Classification of Diseases (ICD), approved in 1989 and updated in 2008, must appear as the basic cause of death to be considered as death-specific for penile cancer.

Deaths were verified by cross-checking data from the HSRC treated patient database and SIM database from 2000 to 2012. The patient's name, date of birth and name of the mother were used as variables to compare databases.

Survival times were calculated in months from the date of diagnosis by histopathology until death by penile cancer (event of interest) or death by other causes (censure). For patients who were alive until the last day of follow-up (January 01, 2000 SIM data there December 31, 2012) were considered censored data, the last visit or medical procedure recorded on the medical record was used as the final date.

Data were organised using Microsoft Office Excel 2007 for Windows. To estimate survival, the 
Kaplan-Meier method was applied. To compare survival curves, the Log Rank test was used with a 5\% significance level. The event of interest was death by penile cancer. The influence of variables was calculated using Cox's multiple regression model. Statistical analysis was performed with Statistical Package for the Social Sciences (SPSS) version 18.0.

The forward stepwise (likelihood ratio) method was applied to select variables after testing other methods for entering variables into the Cox Regression model because it produced the best results. The forward stepwise method relies on individual variable entry, which allows the verification of the significance of each variable and the elimination of non-significant variables. Any variable having a p-value of 0.20 in the univariate test was selected as a candidate for the Cox multivariate model, and the final significance level was $5 \%$.

This study was performed according to the ethical standards determined by the National Research Ethics Commission (Comissão Nacional de Ética em Pesquisa - CONEP), and the study was submitted and approved, using Plataforma Brasil, by the Ethics in Research Committee of the Espírito Santo Federal State University (Universidade Federal do Espírito Santo - UFES).

\section{Results}

The study sample was composed of 100 penile cancer patients who were admitted for treatment at HSRC over an interval of 11 years. At the end of the study, 39 patients had died because of penile cancer, 17 patients had died because of other causes (censored data), and 44 patients were alive (censored data).

The median survival time was 49 months, indicating $50 \%$ of the analysed patients died within that time period. Figure 1 presents the cumulative survival curve, calculated for the outcome of death by penile cancer using the Kaplan-Meier method. The mean survival time was 57.79 months [95\% Confidence Interval (CI): 46.3 - 69.29].

Table 1 presents a description of survival times according to the independent variables of interest. Figures 2A-D present Kaplan-Meier curves for mean survival times as a function of the statistically significant variables described in Table 1 (occupation, origin, presence of compromised lymph nodes and metastasis).

The group composed of 39 patients with rural occupations had a mean survival time of 75.02

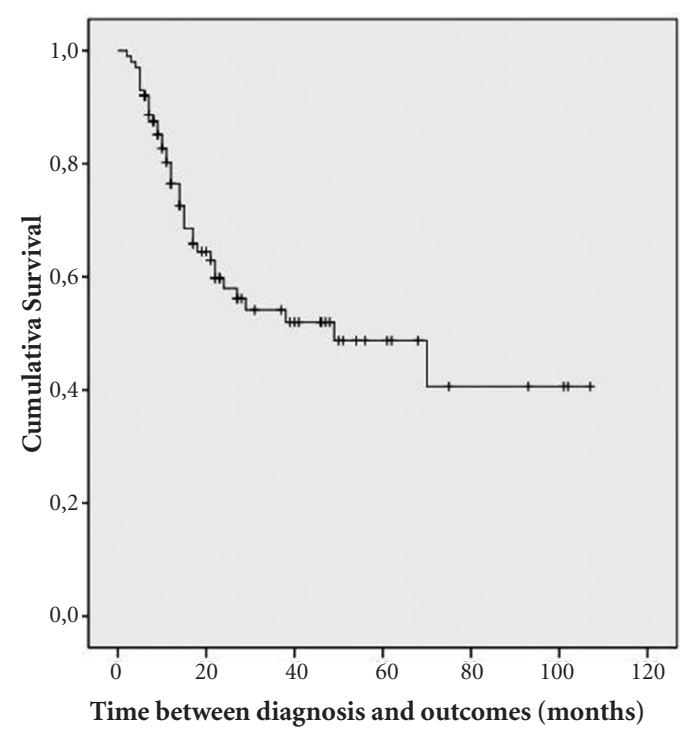

Figure 1. Kaplan-Meier curve for penile cancerspecific survival, Vitória-Espírito Santo, 2000-2011.

months, which was higher than the mean survival time observed in the group of 61 patients with non-rural occupations (42.14 months; $\mathrm{p}=0.036$; Figure 2A).

The variable origin exhibited a considerable impact on survival, as patients from Greater Vitória had a mean survival time of 26.03 months, whereas patients from the interior of Espírito Santo state and other states had a mean survival time of 71.41 months ( $p=0.004$; Figure 2B).

With respect to lymph node invasion, $37 \mathrm{pa}$ tients with compromised lymph nodes had a survival time of 30.59 months, and the remaining 63 patients with no compromised lymph nodes had a survival time of 75.83 months ( $p=0.001$; Figure 2C). Forty-one patients with metastatic disease had a survival time of 28.77 months, and patients with no metastases had a survival time of 83.07 months ( $p=0.001$; Figure 2D).

The log-rank test revealed that the variables race/skin colour, educational level, marital status, source of referral and previous diagnosis were not statistically significant.

Table 2 presents unadjusted and adjusted HR values using Cox's regression model. After multivariate analysis, only the variable metastasis was statistically significant $(\mathrm{HR}=5.18 ; 95 \% \mathrm{CI}: 2.42$ - 11.09). 
Table 1. Survival analysis of men with penile cancer treated, Vitória, Espírito Santo, from 2000 to 2011.

\begin{tabular}{|c|c|c|c|c|c|c|c|}
\hline \multirow{2}{*}{ Variable } & \multirow{2}{*}{ Category } & \multirow{2}{*}{$\mathbf{N}$} & \multirow{2}{*}{ Deaths } & \multicolumn{3}{|c|}{ Survival time (months) } & \multirow{2}{*}{$\frac{\log \text {-ranl }}{p}$} \\
\hline & & & & Mean & 95\% LL & 95\% UL & \\
\hline Total & & 100 & 39 & 57.79 & 46.3 & 69.29 & - \\
\hline \multirow[t]{3}{*}{ Age } & $\leq 40$ years & 18 & 12 & 40.12 & 19.52 & 60.71 & 0.066 \\
\hline & $41-60$ years & 42 & 18 & 54.91 & 39.2 & 70.62 & \\
\hline & $\geq 61$ years & 40 & 9 & 59.43 & 41.08 & 77.77 & \\
\hline \multirow[t]{2}{*}{ Race/skin colour } & Caucasian & 29 & 12 & 31.75 & 23.21 & 40.29 & 0.385 \\
\hline & Non-Caucasian & 69 & 26 & 61.8 & 48.63 & 74.96 & \\
\hline \multirow[t]{2}{*}{ Educational level } & $0-7$ years of study & 67 & 24 & 58.86 & 44.44 & 73.28 & 0.805 \\
\hline & $\geq 8$ years of study & 23 & 11 & 52.32 & 32.61 & 72.03 & \\
\hline \multirow{2}{*}{ Occupation } & Rural & 39 & 10 & 75.02 & 58.53 & 91.51 & 0.036 \\
\hline & Non-rural & 61 & 29 & 42.14 & 30.59 & 53.69 & \\
\hline \multirow[t]{2}{*}{ Origin } & Greater Vitória & 36 & 21 & 26.03 & 19.3 & 32.76 & 0.004 \\
\hline & Interior of ES and other states & 64 & 18 & 71.42 & 57.58 & 85.25 & \\
\hline \multirow[t]{3}{*}{ Marital status } & Single & 25 & 11 & 47.62 & 27.16 & 68.08 & 0.278 \\
\hline & Married, stable union & 62 & 25 & 58.44 & 44.57 & 72.32 & \\
\hline & Separated, widower & 12 & 3 & 48.29 & 36.15 & 60.42 & \\
\hline \multirow[t]{2}{*}{ Source of referral } & Public health services & 70 & 30 & 52.93 & 40.64 & 65.22 & 0.165 \\
\hline & Non-public health Services & 21 & 5 & 76.62 & 54.06 & 99.18 & \\
\hline \multirow[t]{3}{*}{ Previous diagnosis } & $\begin{array}{l}\text { WITHOUT diagnosis and } \\
\text { WITHOUT treatment }\end{array}$ & 30 & 11 & 57.38 & 38.9 & 75.87 & 0.49 \\
\hline & $\begin{array}{l}\text { WITH diagnosis and } \\
\text { WITHOUT treatment }\end{array}$ & 48 & 18 & 63.19 & 48.09 & 78.3 & \\
\hline & $\begin{array}{l}\text { WITH diagnosis } \\
\text { and WITH treatment }\end{array}$ & 22 & 10 & 36.65 & 14.45 & 58.84 & \\
\hline \multirow[t]{2}{*}{ Staging } & Stage I or II & 89 & 32 & 61.11 & 48.91 & 73.32 & 0.084 \\
\hline & Stage III or IV & 11 & 7 & 21.96 & 12.82 & 31.09 & \\
\hline \multirow[t]{2}{*}{ Positive lymph nodes } & Yes & 37 & 24 & 30.59 & 20.98 & 40.2 & 0.001 \\
\hline & No & 63 & 15 & 75.83 & 62.41 & 89.25 & \\
\hline \multirow[t]{2}{*}{ Metastasis } & Yes & 41 & 28 & 28.77 & 20.21 & 37.32 & 0.001 \\
\hline & No & 59 & 11 & 83.07 & 70.44 & 95.7 & \\
\hline
\end{tabular}

\section{Discussion}

At the end of the study, $39 \%$ of patients had died because of penile cancer, the median survival time was 49 months and the mean survival time was approximately 57.8 months. The group of patients with rural occupations had a mean survival time higher than patients with non-rural occupations, patients from Greater Vitória had a mean survival time worse than other customers as well as patients with lymph node invasion and metastatic disease.

Although it is considered a rare cancer, a considerable number of penile cancer cases were observed. The overall survival of the study sample was comparable with the survival of the most advanced cases described in the literature ${ }^{14,15}$. Although the majority of patients enrolled in this study had stage I or II penile cancer, the progres- sion of the disease to poor outcomes in patients with early stage penile cancer treated at HSRC is noteworthy. Another study reported a similar mortality $(38 \%)$ and a low overall survival rate (38 months) ${ }^{16}$.

The spread of penile cancer occurs mainly via the lymphatic system to superficial lymph nodes and then to deep lymph nodes. The spread to pelvic and distant lymph nodes as well as to blood vessels occurs in more advanced cases ${ }^{17}$. In this study sample, an increased unadjusted HR for the outcome death by penile cancer was observed for patients with lymph node invasion. Other studies have reported increased adjusted HR for lymph node-positive patients of $2.45(\mathrm{p}=0.001)^{18}$ and $3.0(\mathrm{p}<0.01)^{13}$. These data indicate that lymph node-positive patients exhibit poorer prognosis ${ }^{13}$.

Patient with penile cancer may have the presence of the Human Papilloma Virus (HPV), virus 

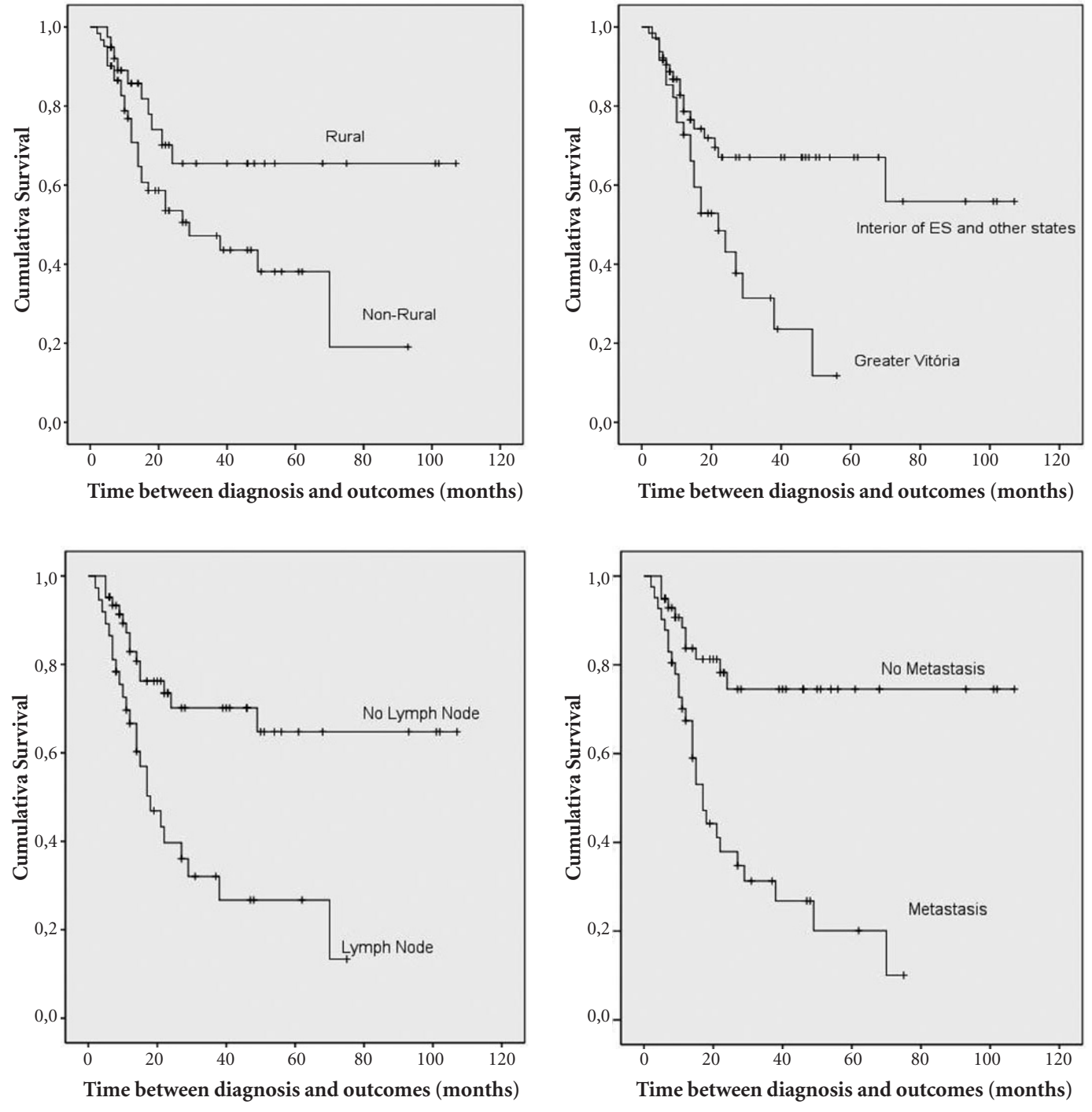

Figure 2. Survival curves of men with penile cancer as a function of the statistically significant variables occupation (2A), origin (2B), presence of compromised lymph nodes (2C) and metastasis (2D).

related to this sexually transmitted disease linked to increased of unprotected sex, which have subtypes with worse prognosis ${ }^{19}$. Therefore, agriculture is the fundamental occupation of the rural men may have penile cancer, with lower linked with HPV and thus better survival. But this statement needs further study. According to a Chinese study ${ }^{20}$, men who live the rural locations have delayed diagnosis of penile cancer, and may demonstrate less aggressive tumor in this population and have better survival.

Following multivariate survival analysis, we observed that metastasis was the only variable that remained statistically significant in our study. In a similar analysis, a Dutch study also identified metastasis as a risk factor for death, with an HR of $2.6(95 \% \text { CI: } 1.3-5.4)^{13}$.

Age, race/skin colour, educational level, marital status, source of referral and previous diagnosis were not statistically significant variables, which may be related to the number of cases in the sample. This study has a limitation with respect to survival estimates for penile cancer, common to most published studies, because it is based on a small number of penile cancer cases present in hospital records, which may be affected by selection bias due to treatment and referral patterns $\mathrm{s}^{21,22}$. 
Table 2. Crude and adjusted hazard ratios (HR) for penile cancer-specific mortality, Vitória-Espírito Santo, 2000-2011.

\begin{tabular}{|c|c|c|c|c|c|c|c|c|c|}
\hline \multirow{2}{*}{ Variable } & \multirow{2}{*}{ Category } & \multicolumn{4}{|c|}{ Unadjusted hazard ratio } & \multicolumn{4}{|c|}{ Adjusted hazard ratio Cox (a) } \\
\hline & & $\mathrm{p}$ & Estimate & LL & UL & $\mathbf{p}$ & Estimate & LL & UL \\
\hline \multirow[t]{3}{*}{ Age } & $\leq 40$ years & 0.026 & 2.68 & 1.12 & 6.38 & 0.211 & & & \\
\hline & 41-60 years & 0.273 & 1.57 & 0.7 & 3.49 & 0.441 & & & \\
\hline & $\geq 61$ years & & 1 & & & & & & \\
\hline \multirow[t]{2}{*}{ Occupation } & Rural & & 1 & & & & & & \\
\hline & Non-rural & 0.042 & 2.11 & 1.03 & 4.35 & 0.1 & & & \\
\hline \multirow[t]{2}{*}{ Origin } & Greater Vitória & 0.006 & 2.49 & 1.3 & 4.75 & 0.052 & & & \\
\hline & $\begin{array}{l}\text { Interior of ES } \\
\text { and other states }\end{array}$ & & 1 & & & & & & \\
\hline \multirow[t]{2}{*}{ Source of referral } & SUS & 0.176 & 1.92 & 0.75 & 4.97 & 0.742 & & & \\
\hline & Non-SUS & & 1 & & & & & & \\
\hline \multirow[t]{2}{*}{ Staging } & Stage I/ II & & 1 & & & & & & \\
\hline & Stage III/ IV & 0.094 & 2.04 & 0.89 & 4.68 & 0.33 & & & \\
\hline \multirow[t]{2}{*}{ Positive lymph nodes } & Yes & 0.001 & 3.08 & 1.61 & 5.88 & 0.59 & & & \\
\hline & No & & 1 & & & & & & \\
\hline \multirow[t]{2}{*}{ Metastasis } & Yes & 0.001 & 4.12 & 2.05 & 8.3 & 0.001 & 5.18 & 2.42 & 11.09 \\
\hline & No & & 1 & & & & 1 & & \\
\hline
\end{tabular}

For this analysis, $91 \%$ of the data were used. (a) Forward stepwise (likelihood ratio) variable selection method.

After analysing data from the HSRC/Afecc Tumour Registry and medical records, a number of variables related to penile cancer, such as phimosis, smoking and HPV, rarely mentioned or even unreported, were observed, preventing analysis depth of the sample. This is a limitation of retrospective studies, there is not systematic collection of information that could have an effect on prognosis of patients.

Care services to treat these patients with penile cancer must disclose information about this disease, which is not known for much of the population, due to rare incidence and certain prejudice. Should discuss and advising on prevention, risk factors, the importance of early diagnosis, the severity of its evolution and the result of mutilating treatment. Opportunities exist centers of multidisciplinary teams references that allow access and an approach not only the physical but also the mental. Considering the large number of patients that progress to depression and suicide.

A better understanding of penile cancer patients would help to establish more effective public policies for the fight against penile cancer. The proposal to implement a Brazilian National Policy for Men's Health (Política Nacional de Atenção Integral à Saúde do Homem) aims to improve the quality of men's health through different actions for health promotion, prevention, care and recovery at the different levels of medical care assistance ${ }^{23}$. Guiding the population in personal hygiene care, transmission of sexually transmitted diseases, HPV vaccination, and dangers of tobacco use, making circumcision available to patients with phimosis, orientating men how to identify a suspicious lesion, and providing specialized medical care according to the population needs would represent important measures to reduce the burden of penile cancer. These measures would prevent the emergence of a disease whose psychological consequences may be irreparable and would provide the earliest and most effective treatment available.

\section{Conclusion}

In Brazil, penile cancer generally affects people of low socioeconomic status and low level of education $^{24}$. Thus, information about the disease for this population are needed. In light of the results obtained in this study, which indicate reduced survival for non-rural workers from Greater Vitória with compromised lymph nodes and metastasis, we believe that early diagnosis and treatment are also needed to improve survival in penile cancer. 


\section{Collaborations}

MAC Souza, SR Zacchi, E Zandonade, MHC Amorim worked on the design, analysis and interpretation of the data, as well as on the writing of the article, on the critical revision and approval of the version to be published. It is responsible for all aspects of the work at ensuring the accuracy and integrity of any part of the work. KCG Viana worked on the design, on the approval of the version to be published. It is responsible for all aspects of the work at ensuring the accuracy and integrity of any part of the work. C Brandão de Souza worked on the design, on the critical revision and approval of the version to be published. It is responsible for all aspects of the work at ensuring the accuracy and integrity of any part of the work.

\section{Acknowledgement}

To Hospital Santa Rita de Cássia/ Associação Feminina de Educação e Combate ao Câncer; To Programa de Pós-Graduação em Saúde Coletiva.

\section{References}

1. World Health Organization (WHO). Classification of Tumours. IARC Publications. Pathology and Genetics of Tumours of the Urinary System and Male Genital Organs. Tumours of the Penis. [acessado 2014 Fev 15]. Disponível em: http://www.iarc.fr/en/publications/pdfs-online/pat-gen/bb7/bb7-chap5.pdf

2. Visser O, Adolfsson J, Rossi S, Verne J, Gatta G, Maffezzini M, Franks KN; RARECARE working group. Incidence and survival of rare urogenital cancers in Europe. Eur J Cancer 2012[acessado 2014 Fev 15]; 48(4):456-464. Disponível em: http://www.ncbi.nlm. nih.gov/pubmed/22119351

3. Micali G, Nasca MR, Innocenzi D, Schwartz RA. Penile cancer. J Am Acad Dermatol 2006[acessado 2014 Fev 15]; 54:369-391. Disponível em: http://www.ncbi.nlm. nih.gov/pubmed/16488287

4. Spiess PE. New treatment guidelines for penile cancer. J Natl Compr Canc Netw 2013[acessado 2014 Fev 15]; 11(5S):659-662. Disponível em: http://www.ncbi.nlm. nih.gov/pubmed/23704237

5. Rippentrop JM, Joslyn SA, Konety BR. Squamous cell carcinoma of the penis: evaluation of data from the surveillance, epidemiology and end results program. Cancer. 2004 [acessado 2014 Fev 15]; 101:1357-63. Disponível em: http://www.ncbi.nlm.nih.gov/pubmed/ 15316902

6. Instituto Nacional de Câncer José Alencar Gomes da Silva (INCA). Tipos de câncer: pênis. [acessado 2014 Fev 15]. Disponível em: http://www2.inca.gov.br/wps/ $\mathrm{wcm} /$ connect/tiposdecancer/site/home/penis.

7. Curtis AP, Donald FL, John W. Tumors of the Penis. In: Wein AJ, Kavoussi LR, Novick AC, Partin AW, Peters CA. Campbell: walsh urology. $9^{\text {th }}$ ed. Philadelphia: Saunders; 2007. p. 967.

8. Trama A, Foschi R, Larrañaga N, Sant M, FuentesRaspall R, Serraino D, Tavilla A, Van Eycken L, Nicolai N; EUROCARE-5 Working Group. Survival of male genital cancers (prostate, testis and penis) in Europe 1999-2007: results from the EUROCARE-5 study. Eur J Cancer 2015[acessado 2014 Fev 15]; 51:2206-2216. Disponível em: http://www.ncbi.nlm.nih.gov/pubmed/26421823

9. Lima SVC, Pontes FA, Lima RS. Tumor de pênis. In: Netto Júnior NR. Urologia prática. 5a ed. São Paulo: Roca; 2008. p. 313.

10. Novara G, Galfano A, De Marco V, Artibani W, Ficarra V. Prognostic factors in squamous cell carcinoma of the penis. Nat Clin Pract Urol 2007 [acessado 2014 Fev 15]; 4(3):140-146. Disponível em: http://www.ncbi.nlm. nih.gov/pubmed/17347658

11. High CRP, Steffens S, Al Ghazal A, Steinestel J, Lehmann R, Wegener G, Schnoeller TJ, Cronauer MV, Jentzmik F, Schrader M, Kuczyk MA, Schrader AJ. High CRP values predict poor survival in patients with penile cancer. BMC Cancer 2013 [acessado 2014 Fev 15]; 13:223. Disponível em: http://bmccancer.biomedcentral.com/articles/10.1186/1471-2407-13-223

12. Presti JC. Genital tumors. In: Tanagho EA, MaAninch JW. Smith's General Urology. 17a ed. Califórnia: McGraw Hill; 2008. p. 386.

13. Hassan E, Carvalhal GF. Câncer de pênis. In: Rhoden EL, organizador. Urologia no consultório. São Paulo: Artmed; 2009. p. 650-662. 
14. Graafland NM, Verhoeven RHA, Coebergh JWW, Horenblas S. Incidence trends and survival of penile squamous cell carcinoma in the Netherlands. Int J Cancer 2011; 128(2):426-432.

15. American Cancer Society. Survival rates for penile câncer. EUA. [Acessado $2014 \mathrm{Fev}$ 16]. Disponível em: http:// www.cancer.org/cancer/penilecancer/detailedguide/ penile-cancer-survival-rates

16. Morrison BF, Hanchard B, Graham RP, Reid ME. Penile cancer in Jamaicans managed at the university hospital of the West Indies. West Indian Med J 2011[citado 2014 Abr 02]; 60(5):525-530. Disponível em: http:// caribbean.scielo.org/scielo.php?script=sci_arttext\&pi$\mathrm{d}=$ S0043-31442011000500005\&lng=pt.

17. Pompeo ACL. Linfadenectomia inguinal estadiada em câncer do pênis: avaliação prospectiva de 50 pacientes [tese]. São Paulo: Universidade de São Paulo; 1993.

18. Djajadiningrat RS, Graafland NM, Werkhoven E, Meinhardt W, Bex A, Poel HG, van Boven HH, Valdés Olmos RA, Horenblas S. Contemporary management of regional nodes in penile cancer-improvement of survival? J Urol. 2014[acessado 2014 Fev 15]; 191(1):68-73. Disponível em: http://www.ncbi.nlm. nih.gov/pubmed/23917166

19. Scheiner MA, Campos MM, Ornellas AA, Chin EW, Ornellas MH, Andrada-Serpa MJ. Human papillomavirus and penile cancers in Rio de Janeiro, Brazil: HPV typing and clinical features. Int. braz j urol. 2008[citado 2016 Jun 26]; 34(4):467-476. Disponível em: http://www.scielo.br/scielo.php?script=sci_arttext\&pi$\mathrm{d}=$ S1677-55382008000400009\&lng=en

20. Gao W, Song L, Yang J, Song N, Wu X, Song N et al. Risk factors and negative consequences of patient's delay for penile carcinoma. World J Surg Oncol. 2016 [citado 2016 Jun 26];14:124. Disponível em: https://wjso.biomedcentral.com/articles/10.1186/s12957-016-0863-z.
21. Mistry T, Jones RW, Dannatt E, Prasad KK, Stockdale AD. A 10-year retrospective audit of penile cancer management in the UK. BJU Int. 2007 [acessado 2014 Fev 15]; 100:1277-81. Disponível em: http://www.ncbi. nlm.nih.gov/pubmed/17850372

22. Soria JC, Fizazi K, Piron D, Kramar A, Gerbaulet A, Haie-Meder C, Perrin JL. Squamous cell carcinoma of the penis: multivariate analysis of prognostic factors and natural history in monocentric study with a conservative policy. Ann Oncol. 1997[acessado 2014 Fev 15]; 8:1089-98. Disponível em: http://www.ncbi.nlm. nih.gov/pubmed/9426328

23. Brasil. Ministério da Saúde (MS). Política Nacional de Atenção Integral à Saúde do Homem. Brasília: MS; 2008. [acessado 2014 Abr 03]. Disponível em: http:// dtr2001.saude.gov.br/sas/PORTARIAS/Port2008/PT09-CONS.pdf

24. Costa S, Rodrigues R, Barbosa L, Silva JO, Branão JOC, Medeiros CSQ. Câncer de pênis: epidemiologia e estratégias de prevenção. Cad Grad 2013 [acessado $2014 \mathrm{Fev}$ 15]; 1(2):23-33. Disponível em: https://periodicos.set. edu.br/index.php/facipesaude/issue/current/showToc

Artigo apresentado em 15/02/2016
Aprovado em 16/08/2016
Versão final apresentada em 18/08/2016 